\title{
Zoogeography of the Holarctic species of the Noctuidae (Lepidoptera): importance of the Beringian refuge
}

\author{
Kauri Mikkola, J. D. Lafontaine \& V. S. Kononenko
}

Mikkola, K., Lafontaine, J. D. \& Kononenko, V. S. 1991: Zoogeography of the Holarctic species of the Noctuidae (Lepidoptera): importance of the Beringian refuge. - Entomol. Fennica 2:157-173.

As a result of published and unpublished revisionary work, literature compilation and expeditions to the Beringian area, 98 species of the Noctuidae are listed as Holarctic and grouped according to their taxonomic and distributional history. Of the 44 species considered to be "naturally" Holarctic before this study, 27 (61\%) are confirmed as Holarctic; 16 species are added on account of range extensions and 29 because of changes in their taxonomic status; 17 taxa are deleted from the Holarctic list. This brings the total of the group to 72 species. Thirteen species are considered to be introduced by man from Europe, a further eight to have been transported by man in the subtropical areas, and five migrant species, three of them of Neotropical origin, may have been assisted by man. The majority of the "naturally" Holarctic species are associated with tundra habitats. The species of dry tundra are frequently endemic to Beringia. In the taiga zone, most Holarctic connections consist of Palaearctic/ Nearctic species pairs. The proportion of Holarctic species decreases from 100 $\%$ in the High Arctic to between 40 and $75 \%$ in Beringia and the northern taiga zone, and from between 10 and $20 \%$ in Newfoundland and Finland to between 2 and $4 \%$ in southern Ontario, Central Europe, Spain and Primorye. Excluding the species supposedly introduced or assisted by man, all Holarctic species occur in the wider Beringian area (Pyrrhia exprimens (Wlk.) has been observed only in Kamchatka and Anaplectoides prasina (D. \& S.) near the southern border of the Yukon); 36/72 (50\%) of the Holarctic species are circumpolar in distribution. The earlier view about Amphiatlantic distributions in the Lepidoptera is refuted. The origin of the Beringian fauna and the mammoth-steppe idea are discussed.

Kauri Mikkola, Department of Zoology, University of Helsinki, P.Rautatiekatu 13, SF-00100 Helsinki, Finland

J. D. Lafontaine, Centre for Land and Biological Resources Research, Biological Division, K.W. Neatby Bldg., Ottawa, Ontario K1A 0C6, Canada V. S. Kononenko, Institute of Biology and Pedology, Far East Scientific Centre, Academy of Sciences USSR, SU-690022 Vladivostok, USSR 
"That so common a Noctuid should have existed for so long a time in two such different forms, under one specific name, seems remarkable ..." (Tams 1917)

\section{Introduction}

Careful taxonomic study of the Holarctic relations in a particular insect group can be expected to produce important data on the speciation, on different zoogeographic phenomena and the history of the continental connections, and also on the kinds of habitats that may have existed during these connections. Petersen (1887) was probably the first to propose faunal exchange between Europe and North America. Later, Lindroth (1957) who made zoogeographic comparisons between the insect faunas of Europe and eastern North America similarly emphasized so-called Amphiatlantic distributions. Finally, he (Lindroth 1963) admitted that about half of the Holarctic elements in insects have a circumpolar distribution, through the "backdoor", i.e. through the Beringian area, the other half being man-assisted introductions.

Croizat (1958) presented a highly sceptical view of the Beringian land bridge as a route for faunal migrations. A handbook of zoogeography, which mainly treats insects (de Lattin 1967), mentions Beringian connections only briefly, and notes (p. 341) that because of the lack of careful comparisons, it is not known whether populations on the two sides of the Bering Strait have diverged at the subspecific level. In a modern treatment of the Canadian fauna, Scudder (1978) presents a distribution map showing an Amphiatlantic distribution from Lindroth (1957).

In recent times, zoogeographic interest has turned from the Atlantic to the Beringian area. In general, however, the knowledge of Holarctic distributions has remained relatively poor: in four recent European handbooks of the Noctuidae, about $2 / 3$ of the Holarctic ratings are erroneous (Table 6).

During the glacial maxima of the past 200000 years, Alaska and the Yukon were effectively a part of the Palaearctic Region. They were united by the Beringian land bridge to northeastern Siberia, but isolated from the rest of the North American continent by the Cordilleran and Laurentide ice sheets (e.g. Hopkins 1982). The "bridge" was actually a very extensive area, at least $1500 \mathrm{~km}$ wide at the narrowest point. The yearly precipitation of Beringia was very low, so glaciers were formed only in some of the higher mountain ranges. These conditions probably reoccurred during the glacial advances of the Illinoian (Riss) and Wisconsinan (Würm) glaciations, the latter ending about 10000 years ago. The most favourable periods for faunal exchange in the Lepidoptera were probably the early deglaciation phases, in which a land bridge still existed but the climate had improved.

These Beringian land bridges were entirely treeless and the main habitat seems to have been relatively unproductive tundra. The mountain slopes on both sides of the land bridge were covered by discontinuous xeric vegetation. Recent palaeontological and stratigraphic research has ended in a debate about the productivity of the Berinigian habitats during the full-glacials (e.g. Colinvaux 1986, Guthrie 1986).

During the Miocene, a few tens of millions of years ago, Eurasia and North America were connected to each other and the climate was mild. What is now Beringia was covered by continuous forests. These were probably mainly deciduous forests with some conifers; continuous coniferous forests were probably lacking. The forest connection between the continents was cut off some 6 million years ago.

To our knowledge, Lindroth's (1971) analysis of the Holarctic Carabidae (Coleoptera) of Alaska was the first entomological attempt at understanding Beringian distributions, but he failed to include western Beringia in his analysis; similarly, Matis (1986) examined some western Beringian insect groups without regard to eastern Beringia. Gorodkov (1976) analysed Holarctic components in the fauna of the Helomyzidae and Scatophagidae (Diptera) of the U.S.S.R.

Until the 1980s, the status of most Holarctic species and Palaearctic/Nearctic species pairs of the Noctuidae was based on superficial examination of the outer appearance and characters of 
the external male genitalia. Moreover, frequently only specimens from Europe and eastern North America were available for study. Thus, at the start of this study, 43 of the 44 species of noctuids considered to be Holarctic in distribution (excluding the species in Table 4) were found either in Europe or in eastern North America.

In the 1980s, we reviewed the status of all conceivable species or species complexes of the Noctuidae showing Holarctic distributions. The study was favoured by two recent developments. First, study material from the critical areas has become available to us, both through our own collecting and through improved cooperation between researchers. Second, improved taxonomic methodology provides better resolution of the status of disjunct populations with slight or no distinctive outer characters. We will discuss these factors below.

From our own material and from literature data, we have so far published a check-list of the Beringian Noctuidae with a zoogeographic discussion (Kononenko et al. 1990) and several revisions of genera, subgenera or species groups (Lafontaine et al. 1983, 1986, 1987a and b, Lafontaine \& Kononenko 1986, 1988a and b). Mikkola \& Kononenko (1986) analysed the ecozoogeographical peculiarity of the subarctic species of the genus Xestia. Lafontaine \& Wood (1988) published a zoogeographic analysis of the Beringian noctuids with reference to the past and present habitats of the area.

The aim of this paper is to treat the zoogeography of the entire Holarctic noctuid fauna, grouping the Holarctic species on an ecological and taxonomic basis, to examine the significance of the Beringian distributions, and to discuss temporal trends in the Holarctic fauna.

\section{Material and methods}

\subsection{Research cooperation between the conti- nents}

The early students of the taxonomy of the North American Noctuidae, A. R. Grote and J. B. Smith, were aware of the European fauna but their approach was not particularly comparative. In North
America, Smith was the first to make genital preparations and to illustrate genitalia. Tams (1917) and Berio (1974) have noted single cases of differing genital structures between the taxa of the continents. J. G. Franclemont and Ch. Boursin, the two most prominent specialists on Noctuidae of the two continents during several decades in the mid-1900s, corresponded for a long period but, unfortunately, did not cooperate in taxonomic reviews of Holarctic species.

For the last few decades, practically no cooperation existed between the continents. In 1980, JDL and VSK began correspondence about the noctuid fauna of northwestern Canada and the northeastern U.S.S.R., and in 1981, KM suggested extending the study area to the entire Holarctic region. During the past decade there has been extensive exchange of materials and correspondence to resolve taxonomic problems. All observed Holarctic species, species pairs and species complexes of the boreal and arctic zones were listed and investigated using the new technique of everting both the male vesicas and the female bursas (see below). Considerable progress was made in 1985 when KM spent one year in Ottawa, Canada, collaborating with JDL.

Our field studies were concentrated on both sides of the Bering Strait. In western Beringia, the biological stations of Aborigen and Kulu in the Upper Kolyma area were visited in five summers, the Anadyr Plateau in one summer, the area of the Amguema River at the base of the Chukchi Peninsula in two summers, and the tip of the Peninsula in one summer. In eastern Beringia, the expeditions were directed mainly to the Yukon, where the main collecting areas were the Ogilvie Mountains (4 summers) and the British Mountains (1 summer).

All noctuid species that occur in the Beringian area, whether Holarctic or not, were treated by Kononenko et al. (1990). The present study deals with all the Holarctic species, summarizing the Holarctic distributions from the paper of Kononenko et al. and adding unpublished data from more southern areas, particularly from the boreal zone. For temperate and subtropical species, the data were mainly compiled from the literature. The results are compared with the North American check-list (Franclemont \& Todd 1983) and with several European check-lists and handbooks. 
The species are considered Holarctic if they are known to have permanent populations both in the Palaearctic and in the Nearctic, i.e. anywhere in these regions to the west and to the east of the Bering Strait. Thus, for instance, the many occasional visitors from North America to the British Isles (cf. Heath \& Emmet 1979, 1983) are not counted.

\subsection{Improved taxomic resolution}

Taxonomic separation of allopatric taxa living on the different continents is problematic, since relatively wide divergence of the outer appearance may be accepted between conspecific taxa. In the outer genitalia also, some geographic variation may be observed. However, if the divergence concerns the inner organs which are crucial for sperm transfer and if corresponding differentiation is observed in both sexes (see Lafontaine \& Mikkola 1987, Mikkola 1992), the conclusion that the taxa are not conspecific has a sound and functional basis.

The experience from intercontinental comparisons is that the vesica of the male interacts with the structure of the female bursa in a complicated way, which ensures that the opening of the spermatophore is positioned against the opening of the ductus seminalis of the female. This has been shown anatomically by Callahan \& Chapin (1960), and the laboratory experiments by Byers \& Hincks (1978) have indicated that small differences in the vesica act as isolating factors. We have observed that in closely related species that show an alternative isolating mechanism (presence/absence of the male scent brushes), the structure of the vesica may be identical (Mikkola \& Lafontaine 1986, Mikkola 1992).

\section{Results and discussion}

\subsection{Holarctic species revised}

The analysis of Holarctic species has necessarily a nomenclatural background. As most species have first been described from Europe, the question of Holarctic occurrence is mainly settled in North America. If the Nearctic taxon is found to be conspecific with the Palaearctic one, the species is
Holarctic in distribution. Therefore the MONA list by Franclemont \& Todd (1983) is our main object of comparison.

Our original belief was that it should be possible to find more Holarctic species, but, as seen from Table 3, we discovered that many species that had been treated as Holarctic in distribution are actually separate species in the Palaearctic and Nearctic Regions. In the MONA list there are 44 species with Holarctic distributions, not including the nearly 20 species that are Holarctic through introductions or assistance by man (or perhaps sometimes by occasional migration of the moths themselves). On further study, one third of these 44 species were found not to be Holarctic and an additional 44 species were added to the list, which brings the number of "naturally" Holarctic species to 72 .

Four recent European handbooks, all preceding the MONA list, make errors in about $2 / 3$ of their ratings of the Holarctic distributions of the "naturally" Holarctic species, according to the present revision (Table 6). The migrants of Table 4 were rated quite correctly, but some authors also included Autographa gamma (L.) as Holarctic, probably being misled by the closely related $A$. californica (Speyer). The distributions of the introduced species were poorly known. The proportion of Holarctic species in the fauna of Eastern Germany must be corrected from $7.7 \%$ (table 4 of Heinicke \& Naumann 1982) to $4.8 \%$.

The species changes in the list of Holarctic noctuids are far from random. The deletions and additions correlate with our understanding of the period when the species from various habitat types were able to live in the forested Beringian area connecting the two continents (Fig. 1) or, later on, to cross the land bridge uncovered from the sea during the glaciations. How the present Holarctic list of Noctuidae was built up is seen in Tables 1-5.

\subsection{Beringian history reflected in the modern distributions}

Changes in Holarctic species may be of significance at the subspecific level, but the borderlines between taxa are frequently not situated at the Bering Strait. Xestia c-nigrum (L.), X. staudingeri 


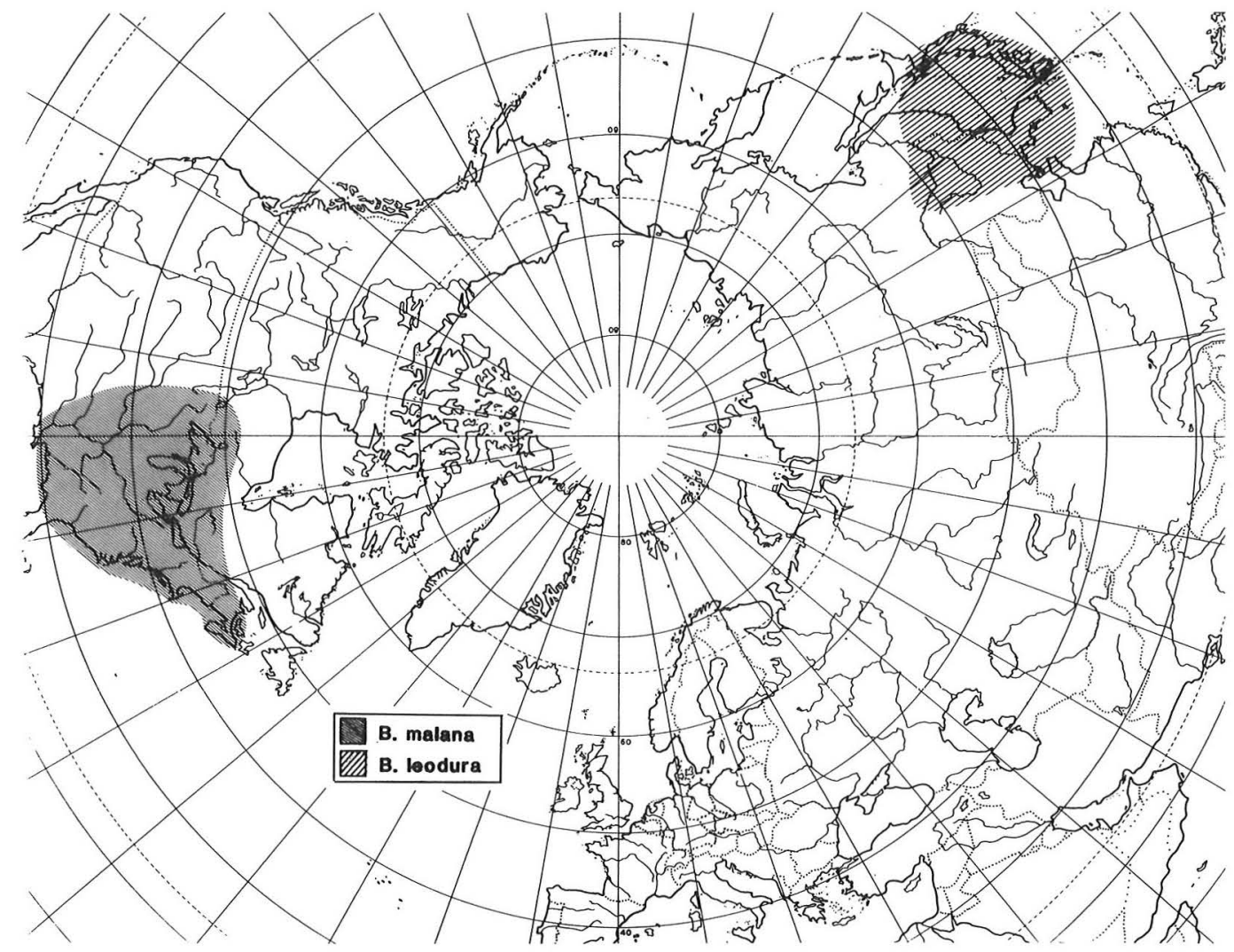

Fig. 1. Distribution of Balsa leodura (Stgr.) and B. malana (Fitch). The closely related sister species, earlier considered conspecific, live in eastern parts of Asia and North America, an ancient disjunction also known from some tree genera.

Table 1. Holarctic species included in the MONA list (Franclemont \& Todd 1983) and confimed in this study, excluding species supposedly introduced or assisted by man (Table 4). Preferred habitat types given as follows (modified from Kononenko et al. 1989): $W T=$ wet (shrub) tundra, $D T=$ dry tundra, $A A=$ arctic-alpine: tundra and mountain tundra in the south, $\mathrm{B}$ = boreal taiga zone, $\mathrm{BM}$ = boreomontane: boreal zone and more southern mountains, $\mathrm{Pl}$ = peatlands and bogs, $D=$ dry lowland habitats such as dunes, steppes and coastal plains, $\mathrm{H}=$ human-affected environments. Total: 27 species.

\begin{tabular}{lrlr}
\hline Scoliopteryx libatrix (L.) & H, B & Papestra biren (Goeze) & BM \\
Syngrapha diasema (Boisd.) & BM, WT, PI & Anarta melanopa (Thnbg.) & WT \\
- interrogationis (L.) & BM, PI & Actebia fennica (Tausch.) & D, B \\
- microgamma (Hb.) & BM, PI & Ochropleura plecta (L.) & B, D, H \\
- parilis (Hb.) & PI, WT & Eurois occultus (L.) & BM, WT \\
Plusia putnami Grt. & H, B & Xestia wockei (Möschl.) & BM, WT \\
Apamea zeta (Tr.) (as exulis) & DT, AA & - staudingeri (Möschl.) & DT \\
Hillia iris (Zett.) & B & - tecta (Hb.) & WT \\
Sympistis zetterstedtii (Stgr.) & DT & - quieta (Hb.) & DT, WT \\
- heliophila (Payk.) & WT, B & Anaplectoides prasina (D. \& S.) & BM, H \\
- lapponica (Thnbg.) & DT & Protexarnis squalida (Gn.) & D \\
- funebris (Hb.) & WT, PI & Heliothis ononis (Fabr.) & D \\
Discestra trifolii (Hfn.) & D, H & Pyrrhia exprimens (Wlk.) & BM \\
Polia richardsoni (Curtis) & DT, WT & & \\
& & &
\end{tabular}


Table 2. Holarctic species added on account of range extensions caused by new finds or redeterminations of older material, or on account of taxonomic change. For the habitat abbreviations, see Table 1.

Range extensions (16 species):

Autographa buraetica (Stgr.)
Apamea rubrirena (Tr.)
Chortodes stigmaticus (Ev.)
Lasionycta skraelingia (H.-S.)
Trichosilia beringiana Laf.\& Kon.
- boreana Laf.
Euxoa hyperborea Laf.
Xestia kolymae (Herz)
- okakensis (Pack.)
- lorezi (Stgr.)
- intermedia (Kon.)
- thula Laf. \& Kon.
- lyngei (Rebel)
- fergusoni Laf.
Parabarrovia keelei Gibson
Chamyla sp. n.

B, $\mathrm{H}$

$\mathrm{BM}$

$B$

$\mathrm{BM}, \mathrm{PI}$ DT (WT)

DT

BM, WT

WT

WT, B, AA

DT

DT

DT

DT

DT

DT

Taxonomic change (29 species):

Polychrysia esmeralda (Oberth.) (=trabea Sm.) B Syngrapha nyiwonis (Mats.) (= ottolenguii Dyar) ${ }^{1} \quad$ B Acronicta vulpina (Grt.) (=leporella Stgr.) stat.rev. B Apamea remissa ( $\mathrm{Hb}$.) (=indocilis Wlk.) $\mathrm{D}, \mathrm{H}$ - sordens (Hfn.) (=finitima Wlk.)

Parastichtis suspecta (Hb.) (=discivaria Wlk.)

D, $\mathrm{H}$ Platyperigea montana (Bremer) (=extima W/k.) B, D Anartomima secedens (Wlk.) (=bohemani Stgr.) BM Lasionycta leucocycla (Stgr.)

(=dovrensis Wocke)

- staudingeri (Aur.)

(=preblei Benj., dolosa B. \& Benj. etc.)

DT, D

Mniotype adusta (Esp.) (= sommeri (Spul.))

Agrotis ruta (Ev.) (=patula Wlk.) WT, $B, B$

Trichosilia nigrita (Graes.) (=acarnea Kozh.) BM

Euxoa lidia (Stoll)

(=thanatologia Dyar, drewseni Stgr.)

- cursoria (Hfn.) (=wirima Hardw.)

- ochrogaster (Gn.) (=islandica Stgr.)

- nomas (Ersch.) (=incognita Sm.)

Chersotis juncta (Grt.) (= andereggii auct.)

Rhyacia quadrangula (Zett.) (=ledereri Ersch.)

D, BM

D

$\mathrm{D}, \mathrm{BM}$

DT

$B, D$

(Epeotis clandestina (Harris) (=suecica Aur) D BM

Graphiphora augur (Fabr.) (=haruspica Grt.) B

Xestia c-nigrum (L.) (=dolosa Ferg.) D, H

- atrata (Morr.) (=filipjevi Shelj.) BM

- ursae (McD.) (=xena Brsn.)

- alaskae (Grt.) (=singularis Kon.)

- liquidaria (Ev.) (=fasciata Skin.)

- rhaetica (Stgr.) (=homogena McD.)

- albuncula (Ev.) (=mallochi Benj.)

- speciosa (Hb.) (=aklavicensis Benj.)

${ }^{1}$ Lafontaine \& Poole 1991.
(Möschl.), Spaelotis clandestina (Harris), Anartomima secedens (Wlk.), Apamea remissa (Hb.), and Sympistis zetterstedtii (Stgr.) are listed as Holarctic species. In each of these one subspecies occurs in the Palaearctic Region and in Nearctic Beringia, but a separate Nearctic subspecies occurs elsewhere in North America (Fig. 2). Xestia tecta (Hb.) and X. okakensis (Pack.) also have a separate eastern subspecies in North America.

Some species long thought to be shared by Europe and North America have been shown to be two separate species, whereas populations in the eastern Palaearctic and western Nearctic have been found to be a single Holarctic species. For instance, Polychrysia moneta (Fabr.) and Acronicta leporina (L.) (Fig. 3) were believed to be represented in North America by the subspecies trabea Smith and vulpina Grt., respectively. The Holarctic species are now P. esmeralda (Oberth.), including ssp. trabea of North America, and A. vulpina of the Nearctic and eastern Palaearctic. The mainly western Palaearctic $P$. moneta and $A$. leporina are species separate from these Holarctic taxa. Xestia mixta (Wlk.), which has been treated as an eastern North American subspecies of Xestia speciosa ( $\mathrm{Hb}$.), is now a separate species and $X$. speciosa is represented in northwestern North America by the subspecies aklavikensis (Benj.), which has formerly been treated as a separate species (Fig. 4).

In a recent check-list, Fibiger \& Hacker (1991) consider, without argumentation, Rhyacia ledereri (Ersch.) to be a species distinct from Rh. quadrangula (Zett.). We have dissected males and females from the Nearctic and Palaearctic Regions and observed that both the external and internal genitalia were identical between the two continents. In contrast, a subspecies of Rhyacia quadrangula, Rh.q. clemens, which occurs in steppe areas of southwestern Canada and western United States, has four rather than three coils in the male vesica and a corresponding number of coils in the female appendix bursae, and is here elevated to the status of a separate species, Rhyacia clemens (Smith), stat. rev. Rhyacia quadrangula (= ledereri) has three coils in the vesica and appendix bursae. In spite of the considerable difference in colour, Rhyacia ledereri and Rh. quadrangula should be considered conspecific until evidence to the contrary is discovered. 
Twenty Holarctic and 12 Nearctic species are limited in North America to eastern Beringia. This kind of distribution is believed to reflect the history of the Beringian area when it was con- tinuous with the Palaearctic but separated from the rest of North America by the continental ice shields. We do not know of any Holarctic species which definitely does not occur in Beringia

Table 3. Species or specific determinations deleted from the list of Holarctic Noctuidae. $-\mathrm{rH}=$ causing reduction of the number of Holarctic species, $\mathrm{rHm}=$ the same but because of misidentification or mislabelling, $\mathrm{rNA}=$ causing reduction in the number of North American species; $R=$ to be treated in future revisions $(B=$ boreal taiga zone, $\mathrm{Pl}=$ peatlands and bogs, $\mathrm{D}=$ dry lowland habitats such as dunes and steppes, $\mathrm{SD}=$ southern deciduous forests, $\mathrm{SA}=$ southern alpine areas).

Polychrysia moneta (Fabr.)

Syngrapha devergens ( $\mathrm{Hb}$.)

Acronicta leporina (L.)

- auricoma (D. \& S.)

Balsa malana (Fitch)

Apamea lateritia ( $\mathrm{Hfn}$.)

Lithomoia solidaginis ( $\mathrm{Hb}$.)

Xanthia togata (Esp.)

Anarta cordigera (Thnbg.)

- myrtilli (L.)

Lasionycta staudingeri (Aur.)

Xestia laetabilis (Zett.)

- imperita $(\mathrm{Hb}$.

- speciosa ( $\mathrm{Hb}$.)

Eugraphe subrosea (Steph.)

Pyrrhia umbra (Hfn.)

Protoschinia scutosa (D. \& S.)

Total: 17 species not = trabea $\mathrm{Sm}$.

not $=$ alticola Wlk., stat.rev.

not $=$ vulpina Grt.

misidentified

not $=$ leodura (Stgr.), stat.rev.

not = germana Morr.

not = luteola Grt. \& Rob.

mislabelled

misidentified, cf. Table 3

misidentified

not $=$ mixta

not = opacifrons $\mathrm{Grt}$.

not $=$ nuchalis Grt., stat. rev.
$\mathrm{rH}$

SA

rNA, rHm

$\begin{array}{rr}r H & S D \\ R, r H & B \\ r H & B \\ R, r H & B \\ r H & P I\end{array}$

$\mathrm{rHm}, \mathrm{rNA}$

$\mathrm{R}, \mathrm{rH}$

B

$\mathrm{rHm}$

$\mathrm{rH}$

$\mathrm{R}, \mathrm{rH}$

$\mathrm{rH}$
PI

D

Table 4. Holarctic species supposedly or certainly introduced or assisted by man.

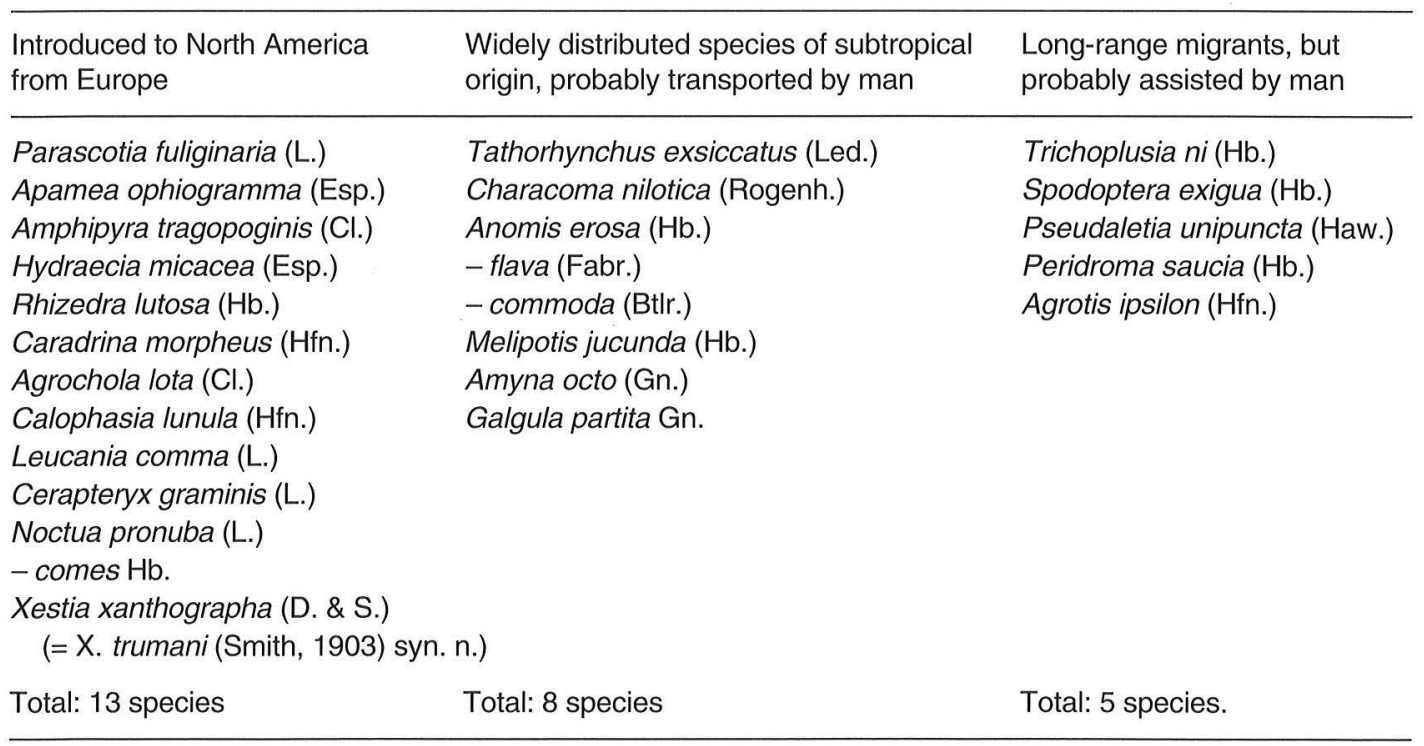




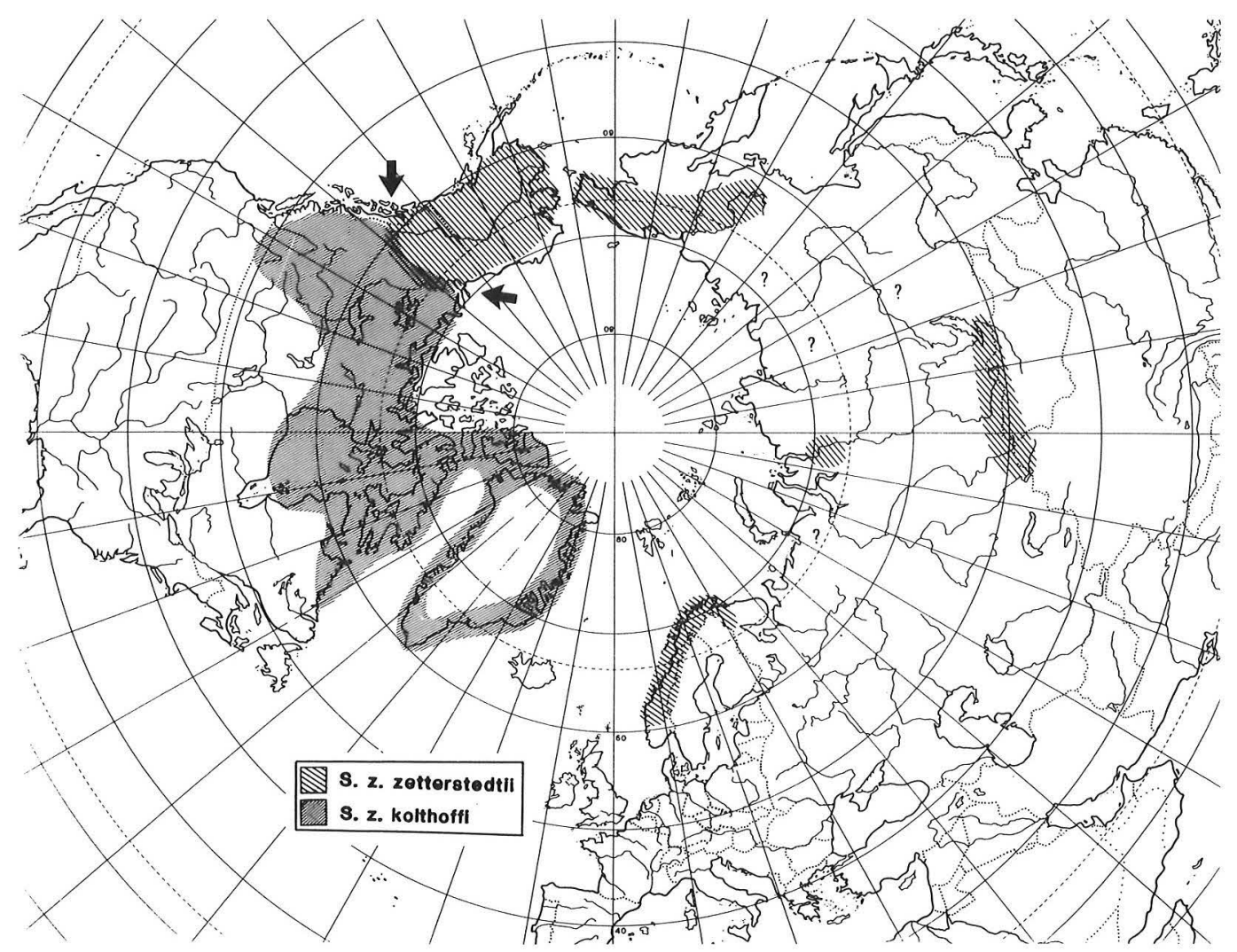

Fig. 2. Differentiation at subspecific level during the Wisconsinan glaciation: Sympistis zetterstedtii (Stgr.) with the nominate subspecies extending to the present Nearctic area. It shows an intergradation zone with the purely Nearctic subspecies S. zetterstedtii kolthoffi (Aurivillius, 1890) stat. rev. in the northwest of North America (arrows).

and which has not been introduced or assisted by man. Actually, Pyrrhia exprimens (Wlk.) has been found only in Kamchatka (Fig. 5) and Anaplectoides prasina (D. \& S.) only close to the southern border of the Yukon, but they most probably occur in Beringia. Acronicta vulpina (Grt.) was first found in Magadanskaya oblast' in the year 1990 (Kullberg et al. 1991). Three Holarctic species have in North America been observed exclusively in the Aleutian Islands: Syngrapha nyiwonis (Mats.), Apamea rubrirena (Tr.) and Chortodes stigmaticus (Ev.).

In general, the proportion of Holarctic species declines steeply from north to south (Table 7, Fig. 6). The absolute number, however, reaches a maximum at more moderate latitudes, centred around Beringia but extending deep into Asia. The effect of glaciations is seen as lower numbers of species in the extremities, in Europe and in eastern North America.

\subsection{Amphiatlantic species}

Lindroth's (1957:231) list of "Primary Amphiatlantic species", i.e. species that occur on both sides of the Atlantic but not in Asia, contains

Table 5. Development of the number of noctuid species considered Holarctic. - A: "Naturally" Holarctic distributions; B: "Non-natural" distributions

\begin{tabular}{lrr}
\hline Study & A & B \\
\hline Franclemont \& Todd (1983) & 44 & 21 \\
This study: & & \\
$\quad$ From Franclemont \& Todd (1983) & 27 & 21 \\
$\quad$ Through range extensions & 16 & 4 \\
$\quad$ Through changes of taxonomic status & 29 & 1 \\
Total & 72 & 26 \\
Total Holarctic species & & 98
\end{tabular}




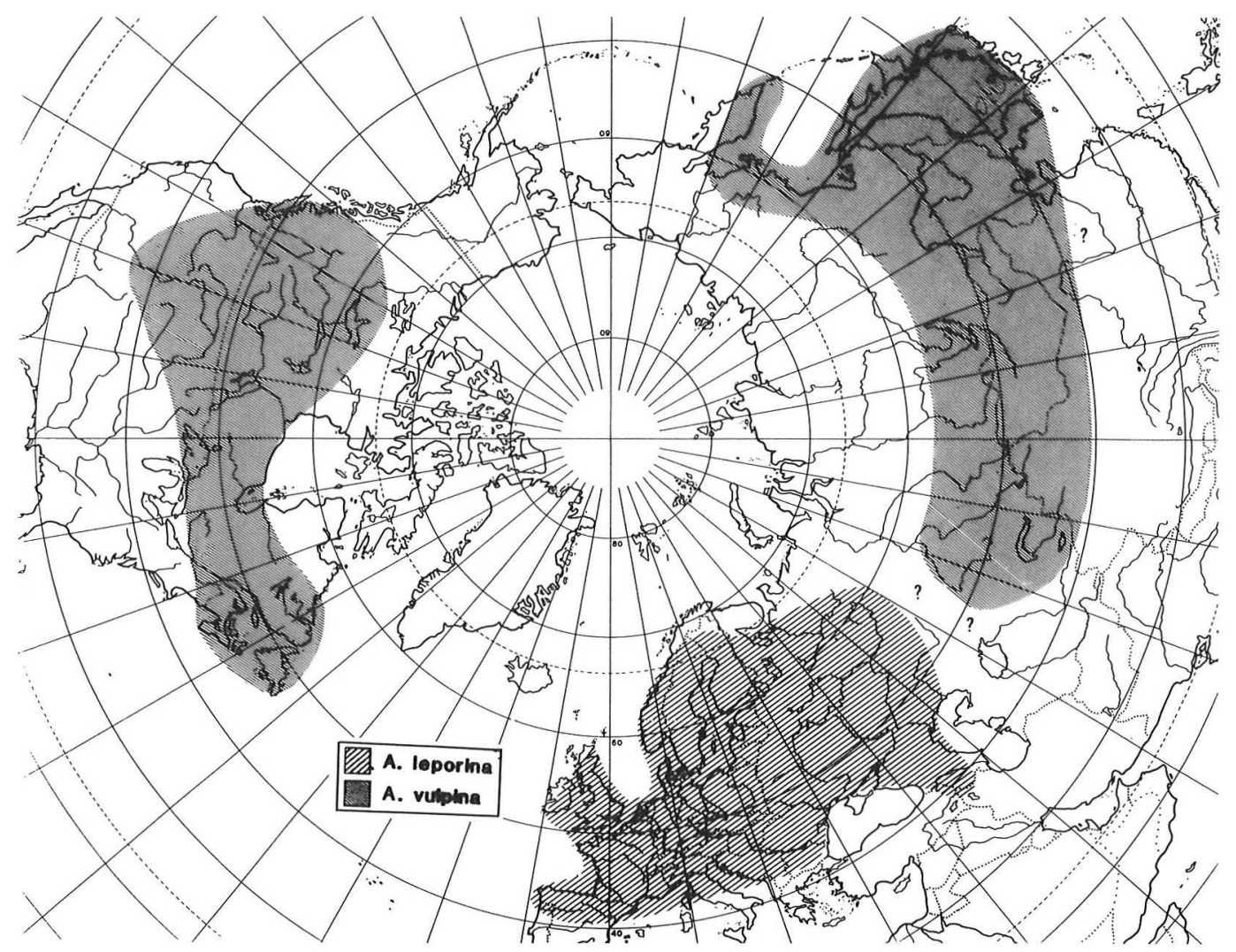

Fig. 3. Distribution of Acronicta leporina auct. after revision and splitting into $A$. leporina (L.) and $A$. vulpina (). The border between the two sister species and the southern border of $A$. vulpina are rather poorly known (question marks).

Table 6. Precision of ratings of Holactic distributions by four recent European handbooks. "Correct" = Holarctic in this revision, the species of Table 5 not included, except the migrants. "Cosmopolitan" accepted as indicating Holarctic distribution. Arrangement from north to south. $-\mathrm{Hol}=$ Number of species correctly rated as Holarctic, $\mathrm{EH}=$ incorrectly rated as Holarctic, $\mathrm{HE}=$ Holarctic rated as non-Holarctic, $\mathrm{E} \%$ $=$ errors $(\mathrm{EH}+\mathrm{HE}$ as percent of total).

\begin{tabular}{lcccc}
\hline Area/handbook & Hol & EH & HE & E\% \\
\hline $\begin{array}{l}\text { Finland } \\
\text { Mikkola \& Jalas 1977, 1979 }\end{array}$ & 25 & 16 & 12 & 52 \\
$\begin{array}{l}\text { Eastern Germany } \\
\text { Heinicke \& Naumann 1982 }\end{array}$ & 14 & 17 & 7 & 63 \\
British Isles & & & & \\
Heath \& Emmet 1979, 1983 & 11 & 17 & 6 & 68 \\
$\begin{array}{l}\text { Spain } \\
\text { Calle 1982 }\end{array}$ & 5 & 20 & 7 & 84 \\
Average & 14 & 18 & 8 & 63 \\
\hline
\end{tabular}

three noctuid moths, (with modern nomenclature) Sympistis lapponica (Thnbg.), Apamea zeta (Tr.) and Syngrapha parilis (Hb.), the first and last being marked with the letter $\mathrm{W}$ meaning "Westarctic". Lindroth also showed distribution maps of these three species. Under less pronounced Westarctic species he listed Syngrapha diasema (Bsd.), Sympistis funebris (Hb.), S. heliophila (Payk.), S. zetterstedtii (Stgr.) (Fig. 2), Hillia iris (Zett.), Spaelotis clandestina (Harris) and Xestia laetabilis (Zett.). Lindroth noted that "Evidently, Noctuid moths are strongly overrepresented among Amphiatlantic (and geographically related) Lepidoptera" and explained this by their superior flight ability.

The Amphiatlantic and Westarctic distributions were interpreted as indicating that the species that have spread to Fennoscandia from the west, though Lindroth (1957:238) admits that this hypothesis was "strongly opposed" by bota- 


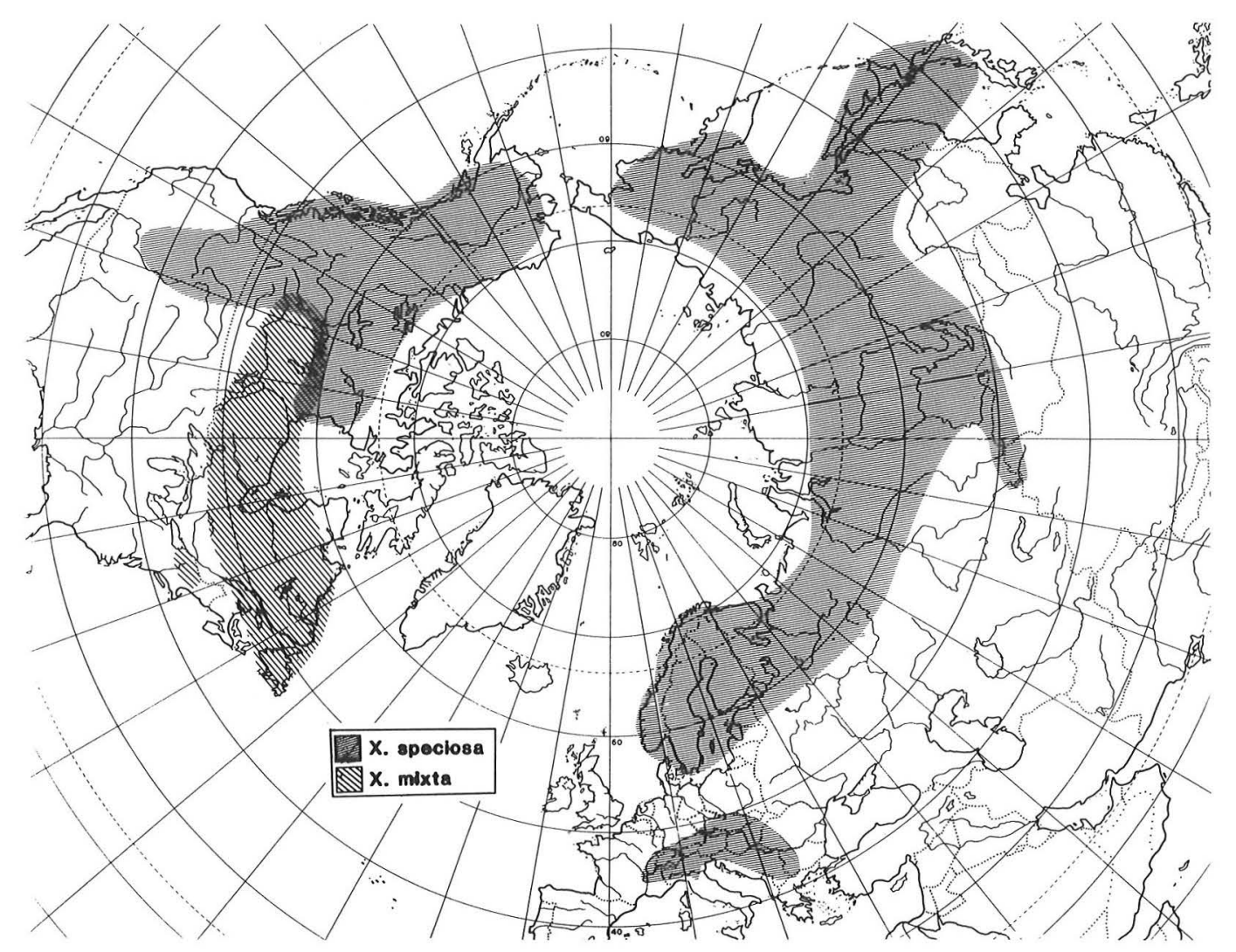

Fig. 4. Distribution of Xestia speciosa (Hb.), with ssp. aklavicensis (Benj.) in North America, and X. mixta (WIk.). The latter probably represents speciation preceding the Wisconsinan glaciation.

nists. Kononenko et al. (1989) show that one of Lindroth's noctuid examples, Xestia laetabilis, is restricted to the Palaearctic and that all the remaining nine not only occur in Asia but that they are all Amphiberingian. Two of the species, $A$. zeta and $S$. zetterstedtii, show a sharp subspecific border at the Atlantic; the latter, at least, is homogeneous on both sides of the Bering Strait (Fig. 2). Thus, the most convincing "Westarctic" lepidopteran group of Lindroth fails to show any Amphiatlantic distributions. The Siberian distributions of the species in question were simply not known about thirty years ago. In an appendix, Lindroth (1957:323) denied that any Amphiatlantic distributions in the Lepidoptera resulted from a past land connection over the Atlantic; he believed that the distributions were the result of dispersal.

\subsection{Are the changes of taxonomic status re- lated to the habitats?}

All the species formerly considered to be Holarctic, but found to be separate species in the Palaearctic and Nearctic (Table 3; rH) have ranges that do not extend north into the shrub tundra zone (10/10) and most of them belong to the arboreal fauna (7/10). These species turned out to be Nearctic/Palaearctic sister species pairs. Many other species pairs of the taiga zone were checked for possible Holarctic species, but they were not conspecific. Arboreal taxa of more southern distribution may show ancient disjunctions (Fig. 1).

In fact, about one half of all species with a general boreal zone distribution represent species pairs in the two zoogeographic regions. This result 


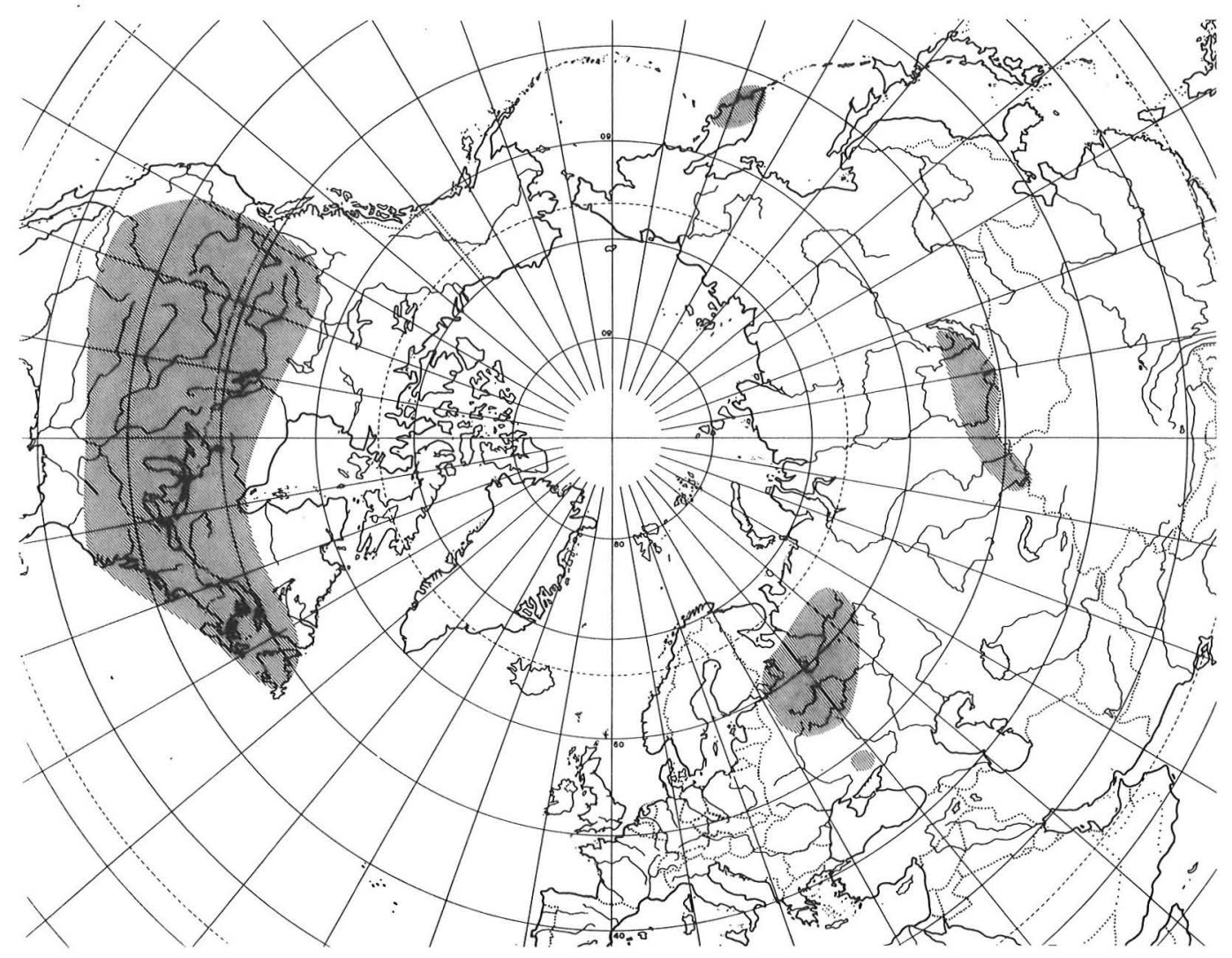

Fig. 5. Distribution of Pyrrhia exprimens (Wlk.), one of the most southern species to show a "naturally" Holarctic distribution.

is not particularly surprising, considering that these forests have not been in contact for at least the past 6 million years. All the tree species of these forests, and many other plants, mammals and birds have differentiated at the species level.

It is more surprising that many of the species associated with open bogs within the boreal forest zone are not tundra species with disjunct southern occurrences and are not Holarctic in distribution. Examples of such bog species are Anarta cordigera (Thnbg.) and A. carbonaria (Christ.) of the Palaearctic and A. luteola (Grt. \& Rob.) of the Nearctic, and also Eugraphe subrosea (Steph.) of the Palaearctic and E. opacifrons (Grt.) of the Nearctic.

Shrub tundra (or wet tundra) habitats, on the other hand, contain species that are Holarctic at about the $70 \%$ level $(18 / 27)$. This habitat was widespread in Beringia and is continuously distributed across the Northern Hemisphere, which allowed its species to become very widespread; many of these species also occur in the south, in the Alps and other mountain ranges. Dry tundra, however, is highly localized to the Beringian area and contains many species endemic to the region. Some of these are Holarctic in that they occur on both sides of the Bering Strait, but the dry tundra is not continuous and only a few species were able to disperse into northern Europe or to the mountains of Southern Siberia, and none occurs in the Alps.

The proportion of Holarctic species in the subgenera of the genus Xestia is particularly illustrative (revised by Lafontaine et al. 1983, 1987a and unpubl.): 


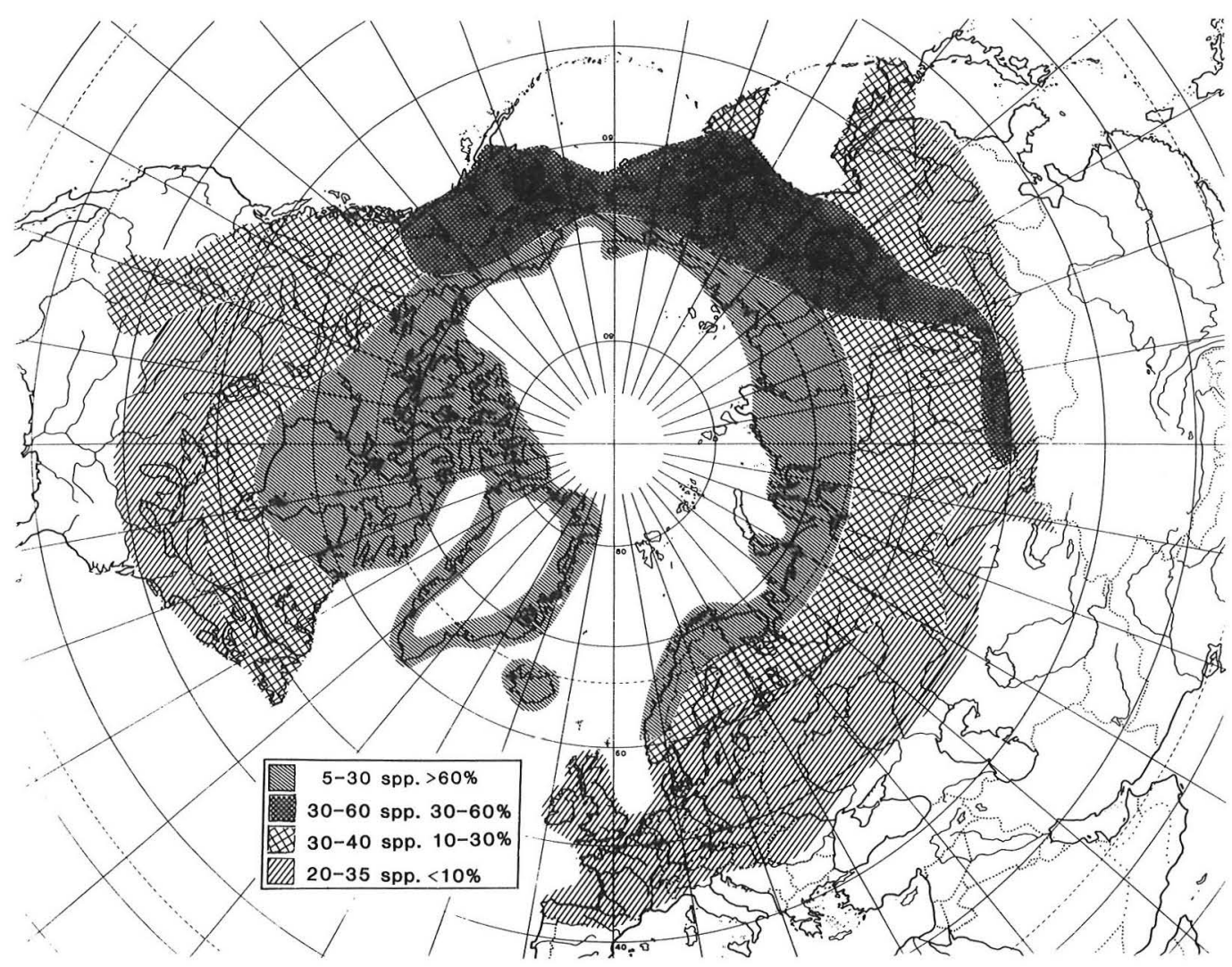

Fig. 6. Number of Holarctic noctuid species and their proportion of the whole noctuid fauna in the Holarctic Region (when exceeding 20 species).

1) All 14 species of the subgenus Schoyenia occur in Beringia, mostly on dry tundra (some on wet tundra) but not more than seven (50 $\%)$ of them are Holarctic.

2) All six species of the subgenus Pachnobia, which live mostly on shrub tundra or in mountain forests near the timber line, occur in Beringia and all six (100\%) are Holarctic.

3) There are 17 species in the subgenus Anomogyna and they are mostly associated with coniferous forests, but several also live in mountainous deciduous forests or even on shrub tundra. Fourteen of the species occur in Beringia, but only three (18\%) are Holarctic; four species have a closely related species on the other continent. All the Holarctic species, Xestia albuncula (Ev.), X. speciosa (Hb.) and $X$. rhaetica (Stgr.), have been observed in habitats devoid of conifers, $X$. al- buncula frequently on tundra. The only Anomogynas which are restricted to one continent without any relatives on the other are the Palaearctic species Xestia sincera (H.-S.) and $X$. brunneopicta (Mats.), which seem to be those most strictly confined to the coniferous forests, the larval host plant of the former being spruce (Picea).

\subsection{Introduced and migrant species}

One quarter of the noctuid species with Holarctic distributions are known or suspected to be introduced or assisted in dispersal by man (Tables 4 and 5). There are 13 temperate species which are certainly or supposedly introduced (Table 4), all of which have spread from Europe to North America. Many introductions are obvious from 
the apparently secondary, human-centred, "immature" distributions; the most common cause of insect introductions is clearly transport on ships (Lindroth 1957). Caradrina morpheus (Hfn.) shows a bipolar distribution around the main harbours of the east and west coasts of North America. Amphipyra tragopogonis (Cl.), known to enter cavities and buildings, may well have entered the ships' cargo spaces. Scoliopteryx libatrix (L.) shows similar behaviour, but its distribution does not suggest introduction and, consequently, the species is treated as "naturally" Holarctic.

Xestia xanthographa (D. \& S.) arrived at the turn of the century, but has been known in North America as X. trumani (Smith, 1903). Hydroecia micacea (Esp.) spread in the 1920s in eastern North America, and Leucania comma (L.) and Cerapteryx graminis (L.) were discovered only in the 1960s and are still restricted to Newfoundland. Agrochola lota $(\mathrm{Cl}$.) is also established in Newfoundland and Parascotia fuliginaria is a new record (Franclemont \& Todd 1983). Calophasia lunula (Hfn.) was de-

Table 7. Proportion of Holarctic species of the Noctuidae (without Nolidae) in selected areas (natural distributions and migrants). The tabulation is based on the following literature and files: 1: Downes 1966; 2 : Downes 1966 and files of JDL; 3, 5 and 7: Kononenko et al. 1990 with later additions; 4: Wolff 1964; 6: Wolff 1971; 8: Morris 1980; 9: Varis et al. 1987; 10: Forster \& Wohlfahrt 1971; 11: Rockburne \& Lafontaine 1976 and files of JDL; 12: Kononenko 1990; 13: Calle 1982; 14: Kimball 1965. - Tot $=$ total number of species, $\mathrm{Hol}$ $=$ Holarctic species, $\mathrm{H} \%$ = percent Holarctic species.

\begin{tabular}{lrrr}
\hline Locality & Tot & Hol & H\% \\
\hline 1. Ellesmere Island, Canada & 5 & 5 & 100 \\
2. Baffin Island, Canada & 14 & 12 & 86 \\
3. Chukchi aut. rep., USSR & 50 & 38 & 76 \\
4. Southern Greenland & 15 & 11 & 73 \\
5. Magadanskaya obl., USSR & 104 & 51 & 49 \\
6. Iceland & 24 & 10 & 42 \\
7. Yukon, Canada & 157 & 64 & 41 \\
8. Newfoundland, Canada & 250 & 41 & 16 \\
9. Finland & 388 & 41 & 10 \\
10. Central Europe & 664 & 28 & 4 \\
11. Ottawa, Canada & 550 & 22 & 4 \\
12. Primorye, USSR & 760 & 24 & 3 \\
13. Spain & 693 & 17 & 2.5 \\
14. Florida, USA & 950 & 4 & 0.4 \\
\hline
\end{tabular}

liberately introduced to control the weed Linaria. It is not known how the recent introductions of Noctua pronuba (L.) and $N$. comes happened; the former arrived in the late 1970s in Nova Scotia and the latter in the 1980s at Vancouver, and both have become common. The Noctua species are not listed by Franclemont \& Todd (1983) (see Table 5). Equally obscure is the mode of arrival in the two most recent introductions: Rhizedra lutosa ( $\mathrm{Hb}$.) (McCabe \& Schweitzer 1991) and Apamea ophiogramma (Esp.) (according to J. Troubridge in litt.) were lately observed at the east coast of the United States and in the Vancouver area, respectively. Both are species of shores or aquatic habitats, the larva of the former living exclusively on Phragmites, and that of the latter also on Phalaris, Glyceria and other grasses (Mikkola \& Jalas 1979).

The eight Holarctic species of more or less subtropical origin (Table 4) may have been transported by shipping, since the larvae of many of them live on plants which are often shipped. Tathorhynchus exsiccatus (Led.) lives on alfalfa (Medicago sativa) (Calle 1982), Anomis flava (Fabr.) on cotton and okra, Eublemma jucundum (Hb.) e.g. on Doxantha (Bignoniaceae) (Covell 1984), and A. commoda (Btlr.) on Hibiscus (Sugi 1982). Characoma nilotica (Rogenh.) has been bred from Tamarix, but is probably polyphagous (Wiltshire 1986). The caterpillar of Amyna octo (Gn.) lives on Chenopodium (Covell 1984), which indicates transportation with ballasts. Galgula partita Gn., which lives on Rumex (Covell 1984) and possibly other plants, was earlier known from the Canary Islands and was recently discovered in continental Spain (Calle 1982). The only species expressly mentioned as migrating (Rockburne \& Lafontaine 1976) is the most marginally Holarctic: in the Palaearctic Anomis erosa (Hb.) has been found only in the Canary Islands (Calle 1982). It is said to live on cotton, Hibiscus and okra (Covell 1984).

The Holarctic noctuids include five species which are pronounced migrants (Table 4). Of these, Pseudaletia unipuncta (Haw.), Peridroma saucia (Hb.) and Agrotis ipsilon (Hfn.) dispersed from west to east, because they belong to South American groups. Thus, only Spodoptera exigua (Hb.) and Trichoplusia $n i$ (Hb.), seem to have dispersed from east to west. Megalographa biloba (Steph.), which has twice reached England, sup- 
posedly with storms over the Atlantic (Heath \& Emmet 1983), is not included.

\section{Conclusions}

The majority of the Holarctic insect species introduced or assisted by man have dispersed from east to west. Lindroth (1957) presents evidence of the role played in this phenomenon by the ballast used in early ship traffic and this is certainly true, at least as concerns the soil fauna. Another reason he presents is that so many European plants were introduced to North America. It hardly explains, however, why so few noctuid moths of American origin live in Europe, particularly as the prevailing westerly winds assist their dispersal. We believe that the question of the age of the agro-ecosystems in the continents and the corresponding difference in competition are still more important factors than suggested by Lindroth (1957). The European agricultural environments would be more or less "saturated" ecosystems, while the corresponding habitats in North America, particularly those already invaded by European plants, are open to noctuid invaders.

In contrast to the introduced species, the migrants have mainly dispersed from west to east, and this may be attributable to windborne transoceanic flights. It is more probable, however, that the ocean crossings have resulted from a combination of migration and introduction: moths from migratory swarms may have landed on offshore ships. The cosmopolitan species not known to be migratory might have attained their wide distribution through assistance by man.

The recent arrival of introduced species is sometimes apparent from the distribution (e.g. occurrence around sea ports), but perhaps more frequently from the fact that no anatomical or outer differentiation is found in specimens of these taxa from the Nearctic and Palaearctic (cf. boreal species, which have mostly differentiated into pairs of species).

The importance of Beringia as a refugium and as a migratory route is seen in the fact that all "naturally" Holarctic species of the Noctuidae have been observed in the Beringian area or very close to it. Of the noctuid species of the Palaearctic Beringia, $51 \%$ are Holarctic. In the family Tor- tricidae the corresponding proportion is lower, $38 \%$ (Kuznetsov \& Mikkola 1991). This difference may be caused partly by the lower mobility of the leaf-rollers, partly by the better faunistic knowledge of the Noctuidae.

Most "naturally" Holarctic species are associated with the tundra zone. The most widespread species usually live on wet (shrub) tundra. There are several species, mostly living on dry tundra, which occur on only one side of Beringia, i.e. are not Holarctic. Species of more boreal distribution that are Holarctic are almost all associated with either Salix or Vaccinium and occur, though less frequently, in the shrub tundra zone as well. They could be viewed as occupying a shrub tundra habitat superimposed on the boreal forest habitat. Similarly, Gorodkov (1976) showed that of the 24 Scatophaga (Diptera) species of the U.S.S.R., 13 are Holarctic and that almost all of these belong to the tundra or are able to invade tundra in the northern part of their range.

The proportion of Holarctic species decreases steeply towards the south (Table 7, Fig. 6). Careful study of the true boreal fauna, especially of the species whose larval host plants are trees, shows that the intercontinental connections usually consist of pairs of sister species in the two zoogeographic regions. This is consistent with the fact that almost all tree species are distinct in the two continents. There is only one exception, Populus balsamifera L., a mainly Nearctic tree species that also grows in the Chukchi Peninsula (Katenin 1980).

Differentiation of taxa during glacial times is often seen as a secondary intergradation zone east of eastern Beringia in NW Canada, between the Beringian or Palaearctic subspecies and the subspecies found elsewhere in North America (Fig. 2). This indicates that the time span of the isolation caused by the glaciation, at least some 15-20 000 years, was enough to cause subspecific differentiation between the Palaearctic/Beringian populations and those south of the Cordilleran and Laurentide ice sheets.

The homogeneity of the taxa of the shrub tundra zone indicates that these species did not have populations south of the Laurentide ice shield, with the exception of Xestia tecta (Hb.) and $X$. okakensis (Pack.), but that they spread from Beringia to the east during postglacial times. The 
interruption of the Beringian connection about 10000 years ago is too recent to have caused any differentiation in their populations.

The pronounced geographical variation in $X$. speciosa (Hb.) in western North America correlates with the glacial history and shows that the split between $X$. speciosa and X. mixta (Wlk.) must be older than the more recent subspeciation in $X$. speciosa. A puzzling question is why $X$. speciosa $(\mathrm{Hb}$.) has not spread to the eastern parts of Canada and X. mixta not to the western parts.

Most species pairs are divided by the Bering Strait. This is not, however, the result of the disappearance of the land connection, but is due to the discontinuity of the forest several millions of years ago. Some species borders are found west of Lake Baikal, supposedly due to the prolonged existence of isolating glacial lakes, "Eisstauseen" (see de Lattin 1967).

Our data do not support the idea of a widespread, continuous "mammoth-steppe" in Beringia. The shrub tundra species were able to cross the land bridge while many dry tundra species were not, which suggests the type of habitat available. Among the Holarctic species, there are three which may live in steppe habitats, but which are common on the tundra of the Siberian mountains (Euxoa ochrogaster (Gn.), E. lidia (Stoll) and Protexarnis squalida (Gn.)), two which commonly live on open shore habitats (Rhyacia quadrangula (Zett.) and Spaelotis clandestina (Harris)), two which live on sand dunes (Euxoa cursoria (Hfn.) and E. hyperborea Laf.) and only one real steppe species (Heliothis ononis (Fabr.)). The occurrence of large herbivores may have been dependent on the productive river valleys rather than on the main biotope of the area (Berman 1990 and oral comm.).

The diversity of the tundra fauna in Beringia has given rise to the idea that Beringia is the place of origin of the tundra fauna. But the distribution tells us little about the place of origin of a taxon, a point emphasized by Eskov \& Golovatch (1986).

Beringian distributions have not been influenced by plate tectonics, since the origin of the tundra biome is too recent for the taxa to have been dispersed by continental drift. On the other hand, the time span from the origin of the tundra biome, some 6-10 million of years, seems too short for the development of taxa at subgeneric level, e.g. the subgenera Schoyenia and Pachnobia of the genus Xestia. As the primitive lineages of Xestia occur in the Palaearctic, we assume that during the Miocene the common ancestors of these subgenera lived in the mountains or steppes of inner Asia rather than of North America, possibly on the ancient Angara plateau as proposed by Kusnezov (1938). The main speciation of the tundra species may have happened during the Pliocene, in an early phase of the tundra biome. During the Pleistocene glaciations, this fauna was driven to the unglaciated Beringia, and in postglacial times the populations spread from there to the west and east. Besides the species distributions of the above-mentioned subgenera (see above), the evidence for this includes the flight years of the Xestia moths, which seem to be the same throughout Beringia but change in the extreme west and east (Mikkola \& Kononenko 1989). Contrary to the view of Kusnezov (1938), the Arctic faunas of Eurasia and North America are clearly of common origin.

Support is thus lacking for the Beringian origin of species now showing an Amphiberingian distribution. A separate group is formed by the species of the dry tundra, many of which have been found on only one side of Beringia. If they had their origin elsewhere, have they become extinct on the other side of Beringia? The fact that some of them, e.g. Trichosilia boreana Laf. and Parabarrovia keelei Gibson, are Amphiberingian, really suggests that others have become extinct on one side of Beringia. This is consistent with the established fact that the dry biotopes of Beringia have shrunk dramatically during the past 10000 years and split into small parts (Hopkins et al. 1982). Therefore we do not believe that Beringia is a centre of speciation, but we consider that the dry tundra fauna of Beringia seems to be formed of fragments of an earlier widespread fauna, many members of which may already have become extinct.

Kusnezov (1938), who did not have data from Beringia, presented the same view about the relict nature of the Arctic fauna ("remnant of former heterogeneity"). His opinion was that there are no systematic groups that could be "special products of adaptation to Arctic conditions". This seems to hold; the few supraspecific taxa of the 
Noctuidae which are typical of and more or less exclusive to the Arctic areas can hardly be such "products", i.e. the two subgenera of Xestia, Schoyenia and Pachnobia, the genus Parabarrovia, and the possibly polyphyletic genus Sympistis. We suspect that these lineages arose at the high elevations in continental areas and moved north as a result of climatic changes. So far, however, we have been unable to locate their ancestors in the Asiatic mountains.

Acknowledgements. We thank Mr. M. Fibiger, Dr. T. L. McCabe, and Mr. J. Troubridge for notes on Characoma nilotica, Rhizedra lutosa, and Apamea ophiogramma, respectively. KM received travel grants from the Academy of Finland and the University of Helsinki.

\section{References}

Berman, D. I. (Берман, Д. И.) 1990: [Present habitats of Morychus viridis (Coleoptera, Byrrhidae) and the reconstruction of the Pleistocene environments in the northeast of the USSR.] (In Russian) - Dokl. Akad. Nauk SSSR 310/4:1021-1023.

Berio, E. 1974: Dypterygia rozmani n. sp. del Maryland (= D. scabriuscula auct. nec L.) (Lepidoptera, Noctuidae). - Boll. Soc. Entomol. Ital. 106:176-177.

Byers, J. R. \& Hincks, C. F. 1978: Biosystematics of the genus Euxoa (Lepidoptera, Noctuidae). XI. Mating discrimination between three closely related species of the declarata group. - Can. J. Zool. 56:1981-1987.

Callahan, P. S. \& Chapin, J. B. 1960: Morphology of the reproductive systems and mating in two representative members of the family Noctuidae, Pseudaletia unipuncta and Peridroma margaritosa, with comparison to Heliothis zea. — Ann. Entomol. Soc. Amer. 53:763782.

Calle, J. A. 1982: Noctuidos Espanoles. - Ministerio de Agricultura, Pesca y Alimentacion. Fuera de Serie 1:1-430.

Colinvaux, P. A. 1986: Plain thinking on Bering Land Bridge vegetation and mammoth populations. - Quart. Rev. Archeol. 7:8-9.

Covell, 1984: A field guide to the moths of eastern North America. - Houghton Mifflin Company, Boston. 496 pp.

Croizat, L. 1958: Panbiogeography. 1. The New World. Wheldon \& Wesley Ltd, Deventer. 1018 pp.

Downes, J. A. 1966: The Lepidoptera of Greenland: some geographic considerations. - Can. Entomol. 98:11351144.

Eskov, K. Y. \& Golovatch, S. I. 1986: On the origin of Trans-Pacific disjunctions. - Zool. Jahrb. Syst. 113:265-285.
Fibiger, M. \& Hacker, H. 1991: Systematic list of the Noctuidae of Europe. - Esperiana 2:1-109.

Forster, W. \& Wohlfahrt, Th. A. 1971: Die Schmetterlinge Mitteleuropas. Eulen (Noctuidae). - Francksche Verlagshandlung, Stuttgart. 329 pp. +32 pl.

Franclemont, J. G. \& Todd, E. L. 1983: Noctuidae. — In: Hodges, R. W. et al. (eds.), Check list of the Lepidoptera of America North of Mexico: 120-159. E. W. Classey Ltd and The Wedge Entomological Foundation, London. $284 \mathrm{pp}$.

Gorodkov, K. В. (Городков, К. Б.) 1976: [Significance of the Bering land bridge in formation of holarctic insect groups as shown by the dipteran families Helomyzidae and Scatophagidae (Diptera).] (In Russian) - In: Kontrimavichus, V. L. (Контримавичус, В. Л.) (ed.), [Beringia in Cenozoic.] Acad. Sci. USSR, Far-Eastern Sci. Centre, Vladivostok. 570 pp.

Guthrie, R. D. 1986: Woolly arguments against the mammoth steppe - a new look at the palynological data. — Quart. Rev. Archaeol. 6:9-16.

Heath, J. \& Emmet, A. M. (eds.) 1979, 1983: The moths and butterflies of Great Britain and Ireland. $9 \& 10$. Curwen Books and Harley Books, London and Colchester. $288+459$ pp.

Heinicke, W. \& Naumann, C. 1982: Beiträge zur Insektenfauna der DDR: Lepidoptera - Noctuidae. - Beitr. Entomol. 30, 31, 32

Hopkins, D. M., Matthews, J. R. Jr., Schweger, C. E. \& Young, S. B. (eds.) 1982: Palaeoecology of Beringia. — Academic Press. 489 pp.

Katenin, А. Е. (Катенин, А. Е.) 1980: American species Populus balsamifera L. (Salicaceae) and Viburnum edule (Michx.) Rafin (Caprifoliaceae) in the southeastern part of Chukotka Peninsula. (In Russian with English summary) - Bot. Zh. 65:414-421.

Kimball, C. P. 1965: Lepidoptera of Florida - an annotated check-list. - Florida Dept. Agric., Gainesville, Florida. 363 pp. +26 pls.

Kononenko, V. S. 1990: Synonymic check-list of the Noctuidae of the Primorye Territory, the Far East of USSR. - Tinea 13, Suppl. 1:1-40.

Kononenko, V. S., Lafontaine, J. D. \& Mikkola, K. 1990: An annotated checklist of noctuid moths (Lepidoptera, Noctuidae) of Beringia. - Entomol. Rev. 69:117138. (First published 1989 in Entomol. Obozhr. 68:549567 ; in Russian)

Kullberg, J., Kuussaari, M. \& Nieminen, M. 1991: Lepidopterological observations from the Upper Kolyma area, northeastern Siberia. - Baptria 16 (in press).

Kusnetsov, N. J. (Куснецов, Н. Й.) 1938: The Arctic fauna of Eurasia and its origin: a study based mainly on Lepidoptera. (In Russian with English summary) — Trudy Zool. Inst. Akad. Nauk SSSR 5:1-85.

Kuznetsov, V. I. \& Mikkola, K. 1991: Toward leaf-roller fauna (Lepidoptera, Noctuidae) of northeastern Siberia, USSR, with descriptions of three new species. Nota Lepidopterol. 14 (in press). 
Lafontaine, J. D. \& Kononenko, V. S. 1986: A revision of the genus Trichosilia Hampson (Lepidoptera: Noctuidae) with descriptions of four new species. - Can. Entomol. 118:1079-1113.

- 1988a: A review of the genus Parabarrovia Gibson (Lepidoptera: Noctuidae) with description of the immature stages and a new species. - Can. Entomol. 120:507-523.

- 1988b: A revision of the Lasionycta skraelingia (Herrich-Schäffer) species complex (Lepidoptera, Noctuidae). - Can. Entomol. 120:903-916.

Lafontaine, J. D., Kononenko, V. S. \& McCabe, T. L. 1986: A review of the Lasionycta leucocycla complex (Lepidoptera: Noctuidae) with descriptions of three new subspecies. - Can. Entomol. 118:255-279.

Lafontaine, J. D. \& Mikkola, K. 1987: Lock-and-key systems in the inner genitalia of Noctuidae (Lepidoptera) as a taxonomic character. (In Swedish with English summary.) - Entomol. Meddel. 55:161-167.

Lafontaine, J. D., Mikkola, K. \& Kononenko, V. S. 1983: A revision of the genus Xestia subg. Schoyenia Auriv. (Lepidoptera: Noctuidae), with descriptions of four new species and a new subspecies. - Entomol. Scand. 14:337-369.

- 1987a: A revision of the genus Xestia subg. Pachnobia (Lepidoptera: Noctuidae), with descriptions of two new subspecies. - Entomol. scand. 18:305-331.

Lafontaine, J. D., Mikkola, K. \& Kononenko, V. S. 1987b: Anarta cordigera (Thunberg) (Lepidoptera: Noctuidae: Hadeninae), a species complex. - Can. Entomol. 119:9331-940.

Latontaine, J. D. \& Yoole, R. W. 1991: Noctuoidea, Noctuidae (Part): Plusiinae. Fasc. 25.1. - In: Dominick, R. B. et al., The moths of America north of Mexico. The Wedge Entomological Foundation, Washington D.C. 182 pp.

Lafontaine, J. D. \& Wood, D. M. 1988: A zoogeographic analysis of the Noctuidae (Lepidoptera) of Beringia, and some inferences about past Beringian habitats. Mem. Entomol. Soc. Can. 144:109-123.

de Lattin, G. 1967: Grundriss der Zoogeographie. — Gustaf Fischer Verlag, Jena. 602 pp.

Lindroth, C. H. 1957: The faunal connections between Europe and North America. - Stockholm. 344 pp.

- 1961: Verbindungen und Barrieren in der zirkumpolaren Verbreitung der Insekten. - XI Int. Congr. Entomol. Wien 1960, 1:438-445.

- 1963: The problem of late land connections in the North Atlantic area. - In: Löve, A. \& Löve, D. (eds.), North Atlantic biota and their history. - Pergamon Press, Oxford.

- 1971: Holarctic elements in the North American fauna. - Proc. XII. Int. Congr. Entomol. Moscow 1968, 1:92-100.

\section{Note added in proof}

Syngrapha ottolenguii (Dyar, 1903) is a senior
Matis, E. G. (Матис, Е. Г.) 1986: [Insects of the Asiatic Beringia.] (In Russian) - Nauka, Moscow. 312 pp.

McCabe, T. L. \& Schweitzer, D. F. 1991: Rhizedra lutosa (Lepidoptera, Noctuidae) newly introduced to North America. - Entomol. News 102:130-132.

Mikkola, K. 1992: Evidence for lock-and-key mechanisms in the internal genitalia of Apamea moths (Lepidoptera, Noctuidae). - Syst. Entomol. 16 (in press).

Mikkola, K. \& Jalas, I. 1977, 1979: Finnish Lepidoptera. Noctuidae $1 \&$ 2. (In Finnish) — Otava, Helsinki. 256 $+304 \mathrm{pp}$.

Mikkola, K. \& Kononenko, V. S. 1989: Flight year of the alternate-year Xestia moths (Lepidoptera, Noctuidae) - A character from the Ice Ages? - Nota Lepidopterol. 12:144-152.

Mikkola, K. \& Lafontaine, J. D. 1986: A preliminary note on the taxonomy of the Apamea zeta complex, with the first report of A. zeta from Fennoscandia (Lepidoptera, Noctuidae). - Notulae Entomol. 66:91-95.

Mikkola, K., Lafontaine, J. D. \& Grotenfelt, P. 1987: A revision of the holarctic Chersotis andereggii complex (Lepidoptera, Noctuidae). — Nota Lepidopterol. 10:140-157.

Morris, R. A. 1980: Butterflies and moths of Newfoundland and Labrador. The macrolepidoptera. - Publ. 1691, Can. Govern. Publ. Centre. Hull, Quebec. 407 pp., 34 pls.

Petersen, W. 1887: Die Lepidopteren-Fauna des arktischen Gebietes von Europa und die Eiszeit. - Inaugural Dissertation, Dorpat. 141 pp.

Rockburne, E. W. \& Lafontaine, J. D. 1976: The cutworm moths of Ontario and Quebec. - Can. Dept. Agric. Publ. 1593:1-164.

Scudder, G. G. E. 1978: Present patterns in the fauna and flora of Canada. - In: Danks, H. V. (ed.), Canada and its insect fauna. Mem. Entomol. Soc. Canada 108:87179.

Sugi, S. 1982: Noctuidae. — In: Inoue, H., Sugi, S., Kuroko, H., Moriuti, S. \& Kawabe, A. (eds.), Moths of Japan. Kodansha, Tokyo. 552 pp. + 392 pl.

Tams, W. H. T. 1917: Euplexia lucipara Linn., as represented in the British Isles and North America. Entomol. Mon. Mag. 3:157-159.

Varis, V., Jalava, J. \& Kyrki, J. 1987: Check-list of Finnish Lepidoptera. - Notulae Entomol. 67:49-118.

Wiltshire, E. P. 1986: Lepidoptera of Saudi Arabia. 5. Fauna of Saudi Arabia 8:262-323.

Wolff, N. L. 1964: The Lepidoptera of Greenland. Meddel. Grönland 159(11):1-74.

- 1971: Lepidoptera. - The Zoology of Iceland 3(45). Ejnar Munksgaard, Copenhagen and Reykjavik. 193 pp. +25 pl.

Received 24.V.1990, revised 16.IV.1991

subjective synonym of $S$. nyiwonis (Matsumura, 1925 ), and the valid name of the taxon in question (pp. 162 and 164). 